\title{
Projected incidence of cardiovascular disease in male firefighters based on current risk factor prevalence
}

\author{
JOHN C. LICCIARDONE, DO \\ R. DONALD HAGAN, PhD \\ STANLEY WEISS, DO \\ ROBERT L. KAMAN, PhD \\ SCOTT C. TAYLOR, DO \\ ROBERT M. WOODWORTH, DO
}

The projected incidence of cardiovascular disease (CVD) in male firefighters was determined by the prevalence of current CVD risk factors and the use of the Framingham Study general cardiovascular risk profile in a probability sample of firefighters from two municipal fire departments. Hypercholesterolemia (60.9\%) and obesity $(56.0 \%)$ were the most prevalent risk factors. Significant age-related trends were observed for the prevalence of all CVD risk factors, except glucose intolerance $(P=.21)$ and an abnormal resting electrocardiogram $(P=.07)$. The projected incidence of CVD in firefighters did not differ from that of the general male population (relative risk, 1.0 ; 95\% confidence interval, 0.7 to 1.4 ); similar risk es-

\footnotetext{
From the department of public health and preventive medicine, Texas College of Osteopathic Medicine, Fort Worth. Dr Licciardone is vice chairman and research director, department of health and preventive medicine, and assistant professor. Drs Hagan, Weiss, Kaman, Taylor, and Woodworth are all associate professors. Dr Weiss is director, division of health and human fitness.
}

Reprint requests to John C Licciardone, DO, department of public health and preventive medicine, Texas College of Osteopathic Medicine, 3500 Camp Bowie Blvd, Fort Worth, TX 76107-2690. timates were observed in age-specific analyses. These findings are in accord with previous incidence and mortality studies that used circulatory diseases as an end point. The present method should be viewed primarily as a hypothesis-generating tool because of its limitations in assessing cause and effect.

The risk of cardiovascular disease (CVD) in firefighters remains controversial. The physical demands of firefighting, stress, and respiratory exposure to smoke, carbon monoxide, and other pollutants are the most common explanations for observed elevations of CVD risk. However, studies of CVD mortality in firefighters have yielded divergent conclusions, ${ }^{1-8}$ and incidence data from the Normative Aging Study do not suggest excess risk. ${ }^{9}$

The risk of CVD in asymptomatic persons may be estimated by either of two frequently used profiles, the Framingham Study general cardiovascular risk profile (FSGCRP) ${ }^{10}$ or the cardiac risk index developed by the Michigan Heart Association (RISKO). ${ }^{11}$ These profiles were used in a sample of 4066 safety personnel, including firefighters, and they had significant value in identifying men in whom symptomatic coronary heart disease would develop. ${ }^{12}$ In addition, the FSGCRP had better predic- 
tive value than RISKO, although a high degree of correlation was observed between the two profiles. The purpose of this study was to determine the prevalence of CVD risk factors in male firefighters and to estimate their risk of having CVD develop by use of the FSGCRP.

\section{Methods}

The target population included male firefighters in the Dallas/Fort Worth (Texas) metroplex. The study was based on a probability sample of firefighters from two municipal fire departments that mandated health and fitness assessments during 1985. Firefighters younger than 40 years were assigned to receive health and fitness assessments by a systematic random sampling scheme. Firefighters between 18 and 29 years of age were assessed triennially, whereas firefighters between 30 and 39 years of age were assessed biennially. Firefighters who were 40 years of age or older were assessed annually.

Participation was limited to subjects free of diseases of the circulatory system, other than essential hypertension. ${ }^{13}$ A total of 460 firefighters participated in health and fitness assessments. Two firefighters were excluded from the study because of confirmed disease of the circulatory system. Six firefighters who were 60 years of age or older were also excluded from the study because of the limited size of this age group. The study included the remaining sample consisting of 452 firefighters.

Health and fitness assessments included a comprehensive history and physical examination, anthropometry, serum chemistry and lipid profiles, electrocardiography (ECG), and exercise testing. Anthropometric measurements included height, weight, and a determination of body composition using skinfold measures as described by Jackson and Pollock. ${ }^{14}$ A random serum specimen was collected for the chemistry and lipid profiles, which were used to determine the presence of glucose intolerance (glucose $>150 \mathrm{mg} / \mathrm{dL}$ ), hypercholesterolemia (total cholesterol $>200 \mathrm{mg} /$ $\mathrm{dL}$ ), and elevation of the total cholesterol to high-density lipoprotein-cholesterol ratio (TC/ HDL >5).

Electrocardiographic abnormalities included left ventricular hypertrophy, ischemic
ST-segment changes, and disturbances of rhythm or conduction.

Exercise testing was based on the modified Balke treadmill protocol, ${ }^{15}$ and ECG evaluation of the test followed the criteria established by the American College of Sports Medicine, Indianapolis. ${ }^{16}$ Downsloping or horizontal ST-segment depression $\geqslant 2 \mathrm{~mm}$ was required for an abnormal test result. Exercise was continued until the subjects achieved a maximal heart rate or until they were forced to stop exercising because of fatigue or other intervening symptoms.

Since older firefighters were oversampled, age-specific analyses were conducted and age adjustment was used to estimate population parameters. The mean and standard error for each variable were calculated for the following age groups: 18 to 29,30 to 39,40 to 49 , and 50 to 59 years. Analysis of variance was used to test for a relationship between age and the main effects, and multiple comparisons were performed using the Newman-Keuls procedure. ${ }^{17}$

The prevalence of ten cardiovascular risk factors was calculated for each of the four age groups and a $\chi^{2}$ test for trend was performed using the method described by Mantel. ${ }^{18}$ The FSGCRP was used to calculate the risk of a cardiovascular event within 8 years for each subject. ${ }^{10}$ Age, total cholesterol level, systolic blood pressure, cigarette smoking history, ECG abnormalities, and glucose intolerance were included as independent variables in the regression equation. The criteria for calculation of CVD risk and the definitions of cardiovascular events paralleled those previously described. ${ }^{19}$ The method of risk calculation and the coefficients for the independent variables are summarized in the Appendix. The relative risk (RR) of CVD was calculated using the general male population parameters established in the Framingham Study, and according to the following equation:

$$
\mathrm{RR}=\frac{\text { Mean FSGCRP Estimate for Male }}{\text { Firefighters }}
$$



The \#1 prescribed allergy pr
in the U.S. and worldwide

RAPID, UNSURPASSED RELIEF

Relief starts fast - most hay fever patients experience significant relief within 1 hour $^{1 \dagger}$

Relief peaks fast - within 3-4 hours ${ }^{2 *}$

Relief is unsurpassed - proven in 30 double-blind clinical studies ${ }^{3-7}$

Relief is convenient - for high patient compliance ${ }^{\dagger \dagger}$

$t$ In most hay fever patients $(55 \%)$.

$* *$ In studies using the histamine-induced skin wheal test.

t $\mathrm{A}$ A summary of 26 studies relating compliance and dosage schedules of various types of medications showed no significant difference in compliance rates between q.d. and b.i.d. dosing. There was significantly greater compliance with q.d. or b.i.d. dosing compared to t.i.d. or q.i.d. dosing $(p<0.05) .{ }^{\circ}$

(C) 1989, Merrell Dow Pharmaceuticals Inc.

Before prescribing Seldane, please see Brief Summary of Prescribing Information,

which appears on the reverse side. 


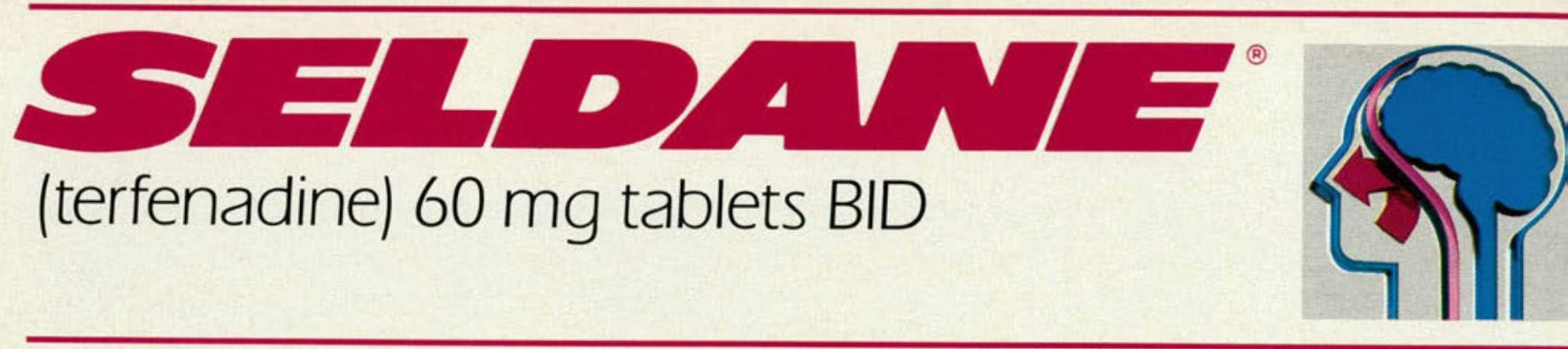

\section{- Fast, unsurpassed relief \\ - Efficacy maintained in through-the-season use ${ }^{9-11}$ \\ - Lets patients stay alert so they can perform at their best \\ - B.i.d. dosing for high patient compliance}

\section{Seldane ${ }^{\circledR}$ (terfenadine) 60 mg Tablets \\ BRIEF SUMMARY \\ CAUTION: Federal law prohibits dispensing without prescription. \\ DESCRIPTION}

Seldane (terfenadine) is available as tablets for oral administration. Each tablet contains $60 \mathrm{mg}$ terfenadine. Tablets also contain, as inactive ingredients: corn starch, gelatin, lactose, magnesium stearate, and sodium bicarbonate.

\section{INDICATIONS AND USAGE}

Seldane is indicated for the relief of symptoms associated with seasonal allergic rinitis such as sneezing, rhinorrhea, pruritus, and lacrimation.

CONTRAINDICATIONS

Seldane is contraindicated in patients with a known hypersensitivity to terfenadine or any of its ingredients.

\section{PRECAUTIONS}

Information for patients

Patients taking Seldane should receive the following information and instructions. Antihistamines are prescribed to reduce allergic symptoms. Patients should be questioned about pregnancy or lactation before starting Seldane therapy, since the drug should be used in pregnancy or lactation only if the potential benefit justifies the potential risk to fetus or baby. Patients should be instructed to take Seldane only as needed and not to exceed the prescribed dose. Patients should also be instructed to store this medication in a tightly closed container in a cool, dry place, away from heat or direct sunlight, and away from children.

Carcinogenesis, mutagenesis, impairment of fertility

Oral doses of terfenadine, corresponding to 63 times the recommended human daily dose, in mice for 18 months or in rats for 24 months, revealed no evidence of tumorigenicity. Microbial and micronucleus test assays with terfenadine have revealed no evidence of mutagenesis.

Reproduction and fertility studies in rats showed no effects on male or female fertility at oral doses of up to 21 times the human daily dose. At 63 times the human daily dose there was a small but significan reduction in implants and at 125 times the human daily dose reduced implants and increased post-implantation losses were observed, which were judged to be secondary to maternal toxicity.

Pregnancy Category C

There was no evidence of animal teratogenicity. Reproduction studies have been performed in rats at doses 63 times and 125 times the human daily dose and have revealed decreased pup weight survival when terfenadine was administered throughout pregnancy and lactation. There are no adequate and well-controlled studies in pregnant women. Seldane should be used during pregnancy only it the potential benefit justifies the potential risk to the fetus.

Nonteratogenic effects

Seldane is not recommended for nursing women. The drug has caused decreased pup weight gain and survival in rats given doses 63 times and 125 times the human daily dose throughout pregnancy and lactation. Effects on pups exposed to Seldane only during lactation are not known, and there are adequate and well-controlled studies in women during lactation.

Pediatric use

Safety and effectiveness of Seldane in children below the age of 12 years have not been established.

General

Consideration should be given to potential anticholinergic (drying) effects in patients with lower airway disease, including asthma.

\section{ADVERSE REACTIONS}

Experience from clinical studies, including both controlled and uncontrolled studies involving more than 2,400 patients who received Seldane, provides information on adverse experience incidence for periods of a few days up to six months. The usual dose in these studies was $60 \mathrm{mg}$ twice daily, but in a small number of patients, the dose was as low as $20 \mathrm{mg}$ twice a day, or as high as $600 \mathrm{mg}$ daily.

In controlled clinical studies using the recommended dose of $60 \mathrm{mg}$ b.i.d., the incidence of reported adverse effects in patients receiving Seldane was similar to that reported in patients receiving placebo (See Table below.) ADVERSE EVENTS REPORTED IN CLINICAL TRIALS

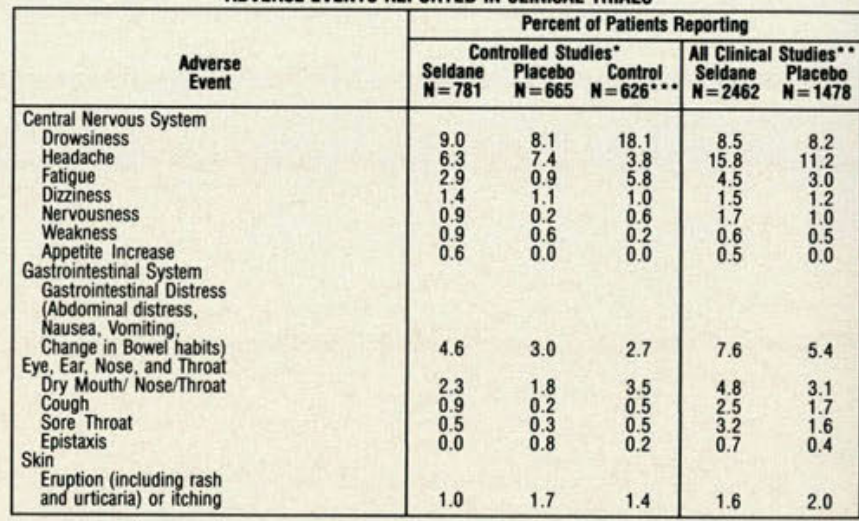

"Duration of treatment in "CONTROLLED STUDIES" was usually 7-14 DAYS.

“Duration of treatment in "ALL CLINICAL STUDIES" was up to 6 months.

CONTROL DRUGS: Chlorpheniramine (291 patients), d-Chlorpheniramine (189 patients), Clemastine (146

In addition to the more frequent side effects reported in clinical trials (See Table), adverse effects hav been reported at a lower incidence in clinical trials and/or spontaneously during marketing of Seldan that warrant listing as possibly associated with drug administration. These include: alopecia, (hair los: or thinning), anaphylaxis, angioedema, arrhythmia (including ventricular tachyarrhythmia), bron chospasm, confusion, depression, galactorrhea, hypotension, insomnia, menstrual disorders (including dysmenorrhea), musculoskeletal symptoms, nightmares, palpitation, paresthesia, photosensitivity, pro longed QT interval, seizures, sweating, syncope, tachycardia, tremor, urinary frequency, and visua disturbances. In clinical trials, several instances of mild, or in one case, moderate transaminast elevations were seen in patients receiving Seldane. Mild elevations were also seen in placebo treatec patients. Marketing experiences include isolated reports of jaundice, cholestatic hepatitis, and hepatitis in most cases available information is incomplete. In neither the clinical trials nor marketing experience is a causal relationship of liver abnormalities to Seldane use clear.

OVERDOSAGE

Information concerning possible overdosage and its treatment appears in Full Prescribing Information DOSAGE AND ADMINISTRATION

The usual dosage for adults and children 12 years and older is $60 \mathrm{mg}$ (1 tablet) twice daily. Product Information as of June, 1988

MERRELL DOW PHARMACEUTICALS INC.

Subsidiary of The Dow Chemical Company

Cincinnati, Ohio 45215, U.S.A.

Merrell Dow

PRINTED IN U.S.A.

References: 1. Murphy-O Connor JC. Renton RL. Westlake DM: Comparative trial of two dose regimens of terfenadine in patients with hay fever. $J$ Int Med Res 1984:12:333-337. 2. Huther KJ. Renftle G. Barraud N, et al: Inhibitory activity of terfenadine on histamine-induced skin wheals in man. Eur J Clin Pharmacol 1977:12:195-199. 3. Kemp JP. Buckley CE, Gershwin ME, et al: Multicenter, double-blind, placebo-controlled trial of terfenadine in seasonal allergic rhinitis and conjunctivitis. Ann Allergy 1985:54:502-509 4. Backhouse Cl. Brewster BS. Lockhart JDF, et al: Terfenadine in allergic rhinitis. A comparative trial of a new

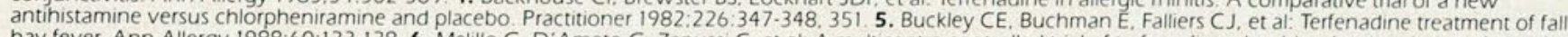

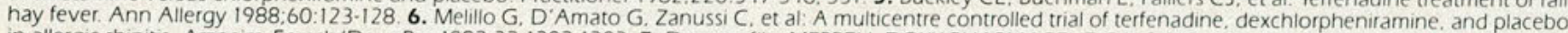
in allergic rhinitis. Arzneim-Forsch/Drug Res 1982:32:1202-1203.7. Data on file. MERRELL DOW PHARMACEUTICALS INC. Cincinnati, Ohio 45215.8. Greenberg RN: Overview of patient compliance with medication dosing: a literature review. Clin Therapeutics 1984:6:592-599.9. Krause LB. Shuster S: The effect of terfenadine on dermographic wealing. Br J Dermatol 1984:10:73-79. 10. Kemp JP. Falliers CJ. Fox RW. et al: A multicenter. open study of the non-sedating antihistamine, terfenadine (Seldane\%), in the maintenance therapy of seasonal allergic rhinitis. Ann Allergy 1988:60:349-354.11. Simons FR, Watson WT. Simons KJ. Lack of subsensitivity to terfenadine during long-term treatment. J Allergy Clin Immunol 1988:82:1068-1075 
The $95 \%$ confidence intervals were estimated using the standard error of the FSGCRP estimate for firefighters.

\section{Results}

As shown in Table 1, age-related trends were evident for most variables. The younger firefighters (aged 18 to 29 years) were more likely to have been nonwhite and single than their older counterparts. In addition, firefighters younger than 40 years also had more years of formal education. Anthropometric data revealed no significant height differences among the four age groups; however, the youngest group was significantly lower in body weight than the other three groups. Body fat percentage was considerably sensitive to age, as significant elevations were noted for each successive age group. Systolic blood pressure, diastolic blood pressure, total cholesterol level, the TC/ HDL ratio, and glucose concentration also demonstrated significant direct relationships with age.

The prevalence rates of CVD risk factors presented in Table 2 reflect many of the characteristics shown in Table 1 . In general, agerelated linear trends were evident for all CVD risk factors except glucose intolerance $(P=.21)$ and an abnormal resting ECG $(P=.07)$. Hypercholesterolemia, elevation of the TC/HDL ratio, and cigarette smoking were most prevalent in the 40- to 49-year-old age group, while the remaining risk factors were most prevalent in the 50- to 59-year-old age group.

The relative risk of CVD developing in firefighters, based on the FSGCRP, is presented in Table 3 . Neither the overall nor the agespecific relative risks were significantly different from unity. Relative risk was not estimated for the 18- to 29- and 30- to 39-year-old age groups, because the low incidence of CVD
Table 1

Characteristics of Participating Firefighters*

Age, yr ${ }^{\dagger}$

$30-39 \quad 40-49 \quad 50-59$

$\begin{array}{cccc}32.0 & (\mathbf{n}=\mathbf{8 4}) & (\mathbf{n}=\mathbf{2 0 9}) & (\mathbf{n}=109) \\ & 13.1 & 13.9 & 8.3\end{array}$

$\begin{array}{llll}\text { (a) } & \text { (b) } & \text { (b) } & \text { (b) }\end{array}$

$\begin{array}{llll}36.0 & 11.9 & 8.6 & 7.3\end{array}$

$\begin{array}{lll}\text { (a) } & \text { (b) } & \text { (b) }\end{array}$

$\begin{array}{llll}13.7(0.2) & 14.1(0.2) & 13.0(0.1) & 12.6(0.2)\end{array}$

$\begin{array}{llll}\text { (a) } & \text { (a) } & \text { (b) }\end{array}$

$\begin{array}{cccc}78.9(1.1) & 180.4(0.6) & 179.4(0.4) & 178.9(0.5) \\ \text { (a) } & \text { (a) } & \text { (a) } & \text { (a) }\end{array}$

$\begin{array}{llll}78.7(2.1) & 84.4(1.2) & 84.8(0.8) & 86.5(1.1)\end{array}$

$\begin{array}{lll}\text { (a) } & \text { (b) } & \text { (b) }\end{array}$

$\begin{array}{llll}3.7(0.9) & 17.0(0.5) \quad 19.4(0.3) \quad 21.9(0.5)\end{array}$

$\begin{array}{llll}\text { (a) } & \text { (b) } & \text { (c) } & \text { (d) }\end{array}$

$\begin{array}{llll}22.5(1.5) & 123.6(1.2) & 124.8(0.9) & 130.3(1.3)\end{array}$

$\begin{array}{lll}\text { (a) (a) } & \text { (a) }\end{array}$

$\begin{array}{llll}76.4(1.3) & 79.4(0.9) & 80.6(0.6) & 83.8(0.8)\end{array}$

$\begin{array}{llll}\text { (a) } & \text { (b) } & \text { (b) }\end{array}$

$\begin{array}{llll}88.8(4.7) & 216.3(4.9) & 234.7(3.1) & 235.2(4.2)\end{array}$
(a)
(b)
(c) (c)

$\begin{array}{cccc}\begin{array}{c}4.2(0.1) \\ \text { (a) }\end{array} & \begin{array}{c}5.1(0.1) \\ \text { (b) }\end{array} & \begin{array}{c}5.8(0.1) \\ \text { (c) }\end{array} & \begin{array}{c}5.7(0.1) \\ \text { (c) }\end{array} \\ \begin{array}{cccc}103.1(1.3) & 104.6(2.0) & 109.4(1.3) & 113.5(2.3) \\ \text { (a) } & \text { (a) } & \text { (ab) } & \text { (b) }\end{array}\end{array}$

$\begin{array}{llll}\text { (a) } & \text { (a) } & \text { (ab) } & \text { (b) }\end{array}$

*Table entries represent a percentage or a mean with the standard error in parentheses.

Age groups with entries that were not significantly different for a variable at the .05 level are denoted by similar letters. at those ages precludes a precise determination of risk in samples of our size.

\section{Discussion}

Strong age-related trends were observed for all variables (Table 1 ) and CVD risk factors (Table 2), with the exception of height, glucose intolerance, and an abnormal resting ECG. The risk of CVD developing in male firefighters, as estimated by the FSGCRP, was not significantly different from that of the general male population (Table 3 ). This suggests that the incidence of CVD in our sample of firefighters should not be excessive in the following 8 years. This projection is concordant with the results of a previous investigation that stud- 
ied the 10-year incidence of coronary heart disease and myocardial infarction in firefighters. ${ }^{9}$

A comparison of our results with those from several previous investigations (Table 4) suggests that the FSGCRP is useful in estimating future CVD incidence and mortality in large occupational cohorts. Our findings were consistent with the results of most investigations, although those studies that included renal diseases as an end point, along with cardiovascular diseases, ${ }^{1,2,4}$ demonstrated higher relative risks. This discrepancy in end points may account for the inconsistency with our results, since the FSGCRP does not include renal diseases as cardiovascular events. It is thus possible that the elevated risk estimates observed in these studies may have been attributable to an excessive risk of renal diseases in firefighters. A direct comparison with these investigations is further limited since nephritis was a more common cause of death during the time period on which their studies were based.

Overall, $8.6 \%$ of firefighters in our sample had abnormal maximal exercise tests. Although tremendous diversity exists in exercise testing protocol and interpretation, two large studies of maximal exercise test results in asymptomatic men used methods similar to ours. ${ }^{20,21}$ Bruce and associates ${ }^{20}$ found abnormal exercise test results in $11.1 \%$ of a cohort of 2365 combined industrial and clinical subjects. Froelicher and coworkers ${ }^{21}$ examined a cohort of 1390 air crewmen and found $10.1 \%$ of the exercise test results to be abnormal. The lower prevalence of abnormal exercise test results in the latter group may be attributed to the larger proportion of younger subjects. The

\begin{tabular}{|c|c|c|c|c|c|c|}
\hline \multicolumn{7}{|c|}{$\begin{array}{c}\text { Table } 2 \\
\text { Prevalence* of Cardiovascular Disease Risk Factors in Firefighters }\end{array}$} \\
\hline \multirow[b]{2}{*}{ Risk Factor } & \multirow[b]{2}{*}{ Overall ${ }^{\dagger}$} & \multicolumn{4}{|c|}{ Age, yr } & \multirow[b]{2}{*}{$P \div$} \\
\hline & & $\begin{array}{l}18-29 \\
(n=50)\end{array}$ & $\begin{array}{c}30-39 \\
(\mathbf{n}=84)\end{array}$ & $\begin{array}{c}40-49 \\
(n=209)\end{array}$ & $\begin{array}{c}50-59 \\
(n=109)\end{array}$ & \\
\hline $\begin{array}{l}\text { Systolic hypertension (systolic blood } \\
\text { pressure }>140 \mathrm{~mm} \mathrm{Hg} \text { ) }\end{array}$ & 6.2 & $0.0(0.0)$ & $3.6(2.0)$ & $7.2(1.8)$ & $20.2(3.9)$ & .02 \\
\hline $\begin{array}{l}\text { Diastolic hypertension (diastolic } \\
\text { blood pressure }>90 \mathrm{~mm} \mathrm{Hg} \text { ) }\end{array}$ & 8.7 & $4.0(2.8)$ & $8.3(3.0)$ & $8.1(1.9)$ & $18.3(3.7)$ & .005 \\
\hline $\begin{array}{l}\text { Hypertension (either systolic or } \\
\text { diastolic hypertension) }\end{array}$ & 12.1 & $4.0(2.8)$ & $11.9(3.6)$ & $12.0(2.3)$ & $26.6(4.4)$ & $<.001$ \\
\hline $\begin{array}{l}\text { Obesity } \\
\text { (body fat }>17 \%)\end{array}$ & 56.0 & $32.0(6.7)$ & $51.2(5.5)$ & $69.4(3.2)$ & $83.5(3.6)$ & $<.001$ \\
\hline $\begin{array}{l}\text { Hypercholesterolemia (serum } \\
\text { cholesterol }>200 \mathrm{mg} / \mathrm{dL} \text { ) }\end{array}$ & 60.9 & $30.0(6.5)$ & $63.1(5.3)$ & $80.4(2.8)$ & $76.1(4.1)$ & $<.001$ \\
\hline $\begin{array}{l}\text { Elevated TC/HDL ratio (total } \\
\text { cholesterol/high-density } \\
\text { lipoprotein-cholesterol ratio }>5 \text { ) }\end{array}$ & 46.6 & $16.0(5.2)$ & $51.2(5.5)$ & $63.2(3.3)$ & $61.5(4.7)$ & $<.001$ \\
\hline $\begin{array}{l}\text { Glucose intolerance (random glucose } \\
\text { concentration }>150 \mathrm{mg} / \mathrm{dL})\end{array}$ & 1.3 & $0.0(0.0)$ & $1.2(1.2)$ & $1.9(1.0)$ & $2.8(1.6)$ & .21 \\
\hline Current smoker & 18.3 & $8.0(3.9)$ & $13.1(3.7)$ & $30.1(3.2)$ & $25.7(4.2)$ & .002 \\
\hline Abnormal resting electrocardiogram & 3.7 & $4.0(2.8)$ & $1.2(1.2)$ & $3.8(1.3)$ & $8.3(2.6)$ & .07 \\
\hline Abnormal exercise test & 5.3 & $0.0(0.0)$ & $0.0(0.0)$ & $9.1(2.0)$ & $18.3(3.7)$ & $<.001$ \\
\hline $\begin{array}{l}\text { *Prevalence is expressed as a percentage } \\
\text { †Prevalence of risk factors in two muni } \\
\text { appropriate weighting factors. } \\
+ \text { Chi-square test for age-related trend in }\end{array}$ & $\begin{array}{l}\text { ith the stand } \\
\text { pal fire depar } \\
\text { sk factor pres }\end{array}$ & $\begin{array}{l}\text { rror in par } \\
\text { ts was est } \\
\end{array}$ & by age ad & t using ą & prevalenc & $\mathrm{s}$, and \\
\hline
\end{tabular}




\begin{tabular}{|ccccc|}
\hline \multicolumn{5}{c|}{$\begin{array}{c}\text { Table 3 } \\
\text { Relative Risk of Cardiovascular Disease in Firefighters* }\end{array}$} \\
\hline & $\begin{array}{c}\text { FSGCRP estimate } \\
\text { for CVD in } \\
\text { firefighters }\end{array}$ & $\begin{array}{c}\text { FSGCRP parameters } \\
\text { for CVD in the } \\
\text { general population }\end{array}$ & $\begin{array}{c}\text { Relative } \\
\text { risk }\end{array}$ & $\begin{array}{c}\text { 95\% } \\
\text { Confidence } \\
\text { interval }\end{array}$ \\
\hline $\begin{array}{c}18-59 \\
(\mathrm{n}=452)\end{array}$ & 0.067 & 0.064 & 1.0 & $0.7-1.4$ \\
$\begin{array}{c}40-49 \\
(\mathrm{n}=209)\end{array}$ & 0.065 & 0.075 & 0.9 & $0.4-1.3$ \\
$\begin{array}{c}50-59 \\
(\mathrm{n}=109)\end{array}$ & 0.139 & 0.159 & 0.9 & $0.4-1.3$ \\
\hline $\begin{array}{c}* \text { FSGCRP indicates Framingham Study general cardiovascular risk profile; CVD, cardiovascular } \\
\text { disease. }\end{array}$ & & & & \\
\hline
\end{tabular}

age distribution of the cohort examined by Bruce and associate ${ }^{20}$ closely resembled that of our sample of firefighters. Thus, exercise testing further suggests that firefighters are not at increased risk of coronary heart disease.

Based on our observations, it appears unlikely that occupational factors such as physical exertion, stress, or respiratory exposures adversely affect the prevalence of CVD risk factors, and ultimately, the incidence of CVD in firefighters. If firefighters are truly at increased risk of CVD mortality, as suggested by some previous findings, ${ }^{1,2,4}$ it is possible that other poorly delineated factors may account for the excess risk. The concept of a "clinical illness promotion factor" has been advanced by Evans ${ }^{22}$ to explain why only in certain persons does clinical illness develop, while in others, illness remains at a subclinical level.

Despite our failure to observe an elevated CVD risk in firefighters as a group, we suggest that physicians or other healthcare professionals dealing with occupational cohorts such as firefighters counsel individual members regarding risk factors for CVD. Our occupational health program consists of physician advice delivered immediately following the health and fitness assessment and a written series of recommendations that are subsequently distributed and discussed by another member of our health-promotion team about 2 weeks later. This follow-up session allows us to address any problems that may occur in the implementation of our recommendations. Since the identification and reversal of multiple risk factors is essential in a program aimed at reducing the incidence of CVD, our staff includes not only physicians, but also departmental faculty in the areas of health promotion, nutrition, and exercise physiology.

Several limitations of our study should be addressed. The firefighters in this study represent a highly selected group that was submitted to strict entrance examinations, periodic health and fitness assessment and riskfactor counseling. Although the prevalence rates of CVD risk factors, such as hypercholesterolemia and obesity, remained high (Table 2), they may have been higher in the absence of such interventions. Therefore, the relative risks observed in Table 3 may actually reflect a combination of two opposing forces: one, the protective effects of selection, periodic evaluation, and counseling, and the other, the potentially detrimental effects of firefighting on the cardiovascular system. Furthermore, information was not available for firefighters who resigned or who were dismissed from their positions; these firefighters may have been at higher risk of CVD than the participants (only two participants had confirmed CVD; however, 39 had abnormal exercise test results).

The use of the general male population parameters for the FSGCRP was not entirely appropriate in calculating the relative risk of CVD in this occupational study. A more useful comparison would involve other occupational cohorts; however, information about the FSGCRP in such cohorts is lacking. In this regard, the comparison based on exercise testing was more appropriate since an industrial cohort was included in one study ${ }^{20}$; however, 
our conclusions remain unaltered when based on the results of exercise testing.

A further limitation of our study was its cross-sectional nature. Such studies are not especially useful in the assessment of causality, although this was not an important issue in our study, because an association between firefighting and CVD risk was not observed. An extension of the present study includes measurement of the longitudinal changes in the
FSGCRP in firefighters as compared with changes in the general population or a more suitable occupational cohort.

\section{Summary}

By use of the present method, the projected incidence of CVD in male firefighters did not differ from that of the general male population. Our findings are in accord with those of several previous investigators ${ }^{2.3 .5-9}$ who meas-

\begin{tabular}{|c|c|c|c|c|c|}
\hline \multicolumn{6}{|c|}{$\begin{array}{c}\text { Table } 4 \\
\begin{array}{c}\text { Comparison of Present Results With the Findings of Previous Investigations } \\
\text { of Cardiovascular Disease Risk in Firefighters* }\end{array}\end{array}$} \\
\hline \multirow[b]{2}{*}{ End point } & \multirow{2}{*}{$\begin{array}{c}\text { Risk } \\
\text { estimate }\end{array}$} & \multicolumn{2}{|c|}{ Significance test } & \multirow{2}{*}{$\begin{array}{l}\text { Time } \\
\text { period } \\
\text { studied }\end{array}$} & \multirow[b]{2}{*}{ Reference } \\
\hline & & $95 \% \mathrm{CI}$ & $P$ & & \\
\hline $\begin{array}{l}\text { Prevalence } \\
\text { (CVDRF) }\end{array}$ & 1.0 (RR) & $0.7-1.4$ & NS & 1985 & Present study \\
\hline $\begin{array}{l}\text { Incidence } \\
\text { (CHD) }\end{array}$ & $0.5(\mathrm{RR})$ & $0.2-1.4$ & .19 & $1963-1973$ & Dibbs et al ${ }^{9}$ \\
\hline $\begin{array}{l}\text { Incidence } \\
\text { (MI) }\end{array}$ & 0.5 (RR) & $0.1-1.9$ & .31 & 1963-1973 & Dibbs et $\mathrm{al}^{9}$ \\
\hline $\begin{array}{l}\text { Mortality } \\
\text { (CD) }\end{array}$ & 0.9 (SMR) & $\cdots$ & $\cdots$ & $1915-1975$ & Musk et al 6 \\
\hline $\begin{array}{l}\text { Mortality } \\
\text { (CD) }\end{array}$ & 0.8 (SMR) & $0.6-1.0$ & $\cdots$ & 1939-1978 & $\begin{array}{l}\text { Eliopulos } \\
\text { et } \mathrm{al}^{7}\end{array}$ \\
\hline $\begin{array}{l}\text { Mortality } \\
\text { (CD) }\end{array}$ & 1.6 (SMR) & $\cdots$ & NS & 1950 & Guralnick ${ }^{4}$ \\
\hline $\begin{array}{l}\text { Mortality } \\
\text { (CD) }\end{array}$ & 1.0 (PMR) & $\cdots$ & NS & $1950-1971$ & Milham $^{3}$ \\
\hline $\begin{array}{l}\text { Mortality } \\
\text { (CD) }\end{array}$ & 1.1 (PMR) & $\cdots$ & NS & $1974-1980$ & $\begin{array}{l}\text { Feuer and } \\
\text { Rosenman }^{8}\end{array}$ \\
\hline $\begin{array}{l}\text { Mortality } \\
\text { (CHD) }\end{array}$ & 1.1 (PMR) & $\cdots$ & $\cdots$ & $1937-1939$ & $\begin{array}{l}\text { Dublin and } \\
\text { Vane }^{2}\end{array}$ \\
\hline $\begin{array}{l}\text { Mortality } \\
\text { (CHD) }\end{array}$ & 1.1 (PMR) & $\cdots$ & NS & 1967 & Decoufle et $\mathrm{al}^{5}$ \\
\hline $\begin{array}{l}\text { Mortality } \\
\text { (CRD) }\end{array}$ & 1.4 (SMR) & $\cdots$ & $<.001$ & $1921-1953$ & $\begin{array}{l}\text { Mastromat- } \\
\text { teo }{ }^{1}\end{array}$ \\
\hline $\begin{array}{l}\text { Mortality } \\
\text { (CRD) }\end{array}$ & 1.3 (PMR) & $\cdots$ & $\cdots$ & $1937-1939$ & $\begin{array}{l}\text { Dublin and } \\
\text { Vane }^{2}\end{array}$ \\
\hline $\begin{array}{l}\text { Mortality } \\
\text { (CRD) }\end{array}$ & 1.6 (SMR) & $\cdots$ & NS & 1950 & Guralnick $^{4}$ \\
\hline $\begin{array}{l}{ }^{*} \mathrm{CI} \text { indicate } \\
\text { heart disease; } \\
\text { disease; RR, } \\
\text { ratio; and NS, } \\
\text { +Investigati }\end{array}$ & $\begin{array}{l}\text { dence interve } \\
\text { nyocardial in } \\
\text { risk; SMR, } \\
\text { gnificant at } t \\
\text { at did not rep }\end{array}$ & $\begin{array}{l}\text {; CVDRF, ca } \\
\text { arction; CD, } \\
\text { tandardized } \\
\text { e .05 level. } \\
\text { rt significan }\end{array}$ & $\begin{array}{l}\text { Hiovascul: } \\
\text { irculatory } \\
\text { nortality } \\
\text { tests ar }\end{array}$ & $\begin{array}{l}\text { disease risk fac } \\
\text { disease; CRD, c } \\
\text { atio; PMR, prop } \\
\text { denoted by ellip }\end{array}$ & $\begin{array}{l}\text { rs; CHD, coronary } \\
\text { diovascular-renal } \\
\text { tionate mortality }\end{array}$ \\
\hline
\end{tabular}


ured incidence of and mortality from CVD. Although our method has limitations, it may be useful for generating hypotheses about CVD risk in other occupational cohorts, which may then be studied by more rigorous epidemiologic methods.

\section{See appendix on page 1302 .}

1. Mastromatteo E: Mortality in city firemen. II: A study of mortality in firemen of a city fire department. Arch Indust Health 1959;20:227-233.

2. Dublin LI, Vane RJ: Occupational mortality experience of insured wage earners. Monthly Labor Review 1947;64:10031018 .

3. Milham S: Occupational Mortality in Washington State, 1950 1971. Cincinnati, Ohio, US Department of Health, Education, and Welfare, Public Health Service, Center for Disease Control, National Institute for Occupational Safety and Health, 1976, vol 3, pp 747-756.

4. Guralnick L: Mortality by occupation and cause of death among men 20-64 years of age. United States 1950 Vital Statistics, Special Reports. Washington, DC, US Department of Health, Education, and Welfare, Public Health Service, National Vital Statistics Division, 1963, vol 53, p 279.

5. Decoufle P, Lloyd JW, Salvin LG: Mortality by cause among stationary engineers and stationary firemen. $J$ Occup Med 1977;19:679-682.

6. Musk AW, Monson RR, Peters JM, et al: Mortality among Boston firefighters, 1915-1975. Br J Indust Med 1978;35:104108.

7. Eliopulos E, Armstrong BK, Spickett JT, et al: Mortality of firefighters in Western Australia. Br J Indust Med 1984;41:183187.

8. Feuer E, Rosenman K: Mortality in police and firefighters in New Jersey. Am J Indust Med 1986;9:517-527.

9. Dibbs E, Thomas HE, Weiss ST, et al: Fire fighting and coronary heart disease. Circulation 1982;65:943-946.

10. Kannel WB, McGee D, Gordon T: A general cardiovascular risk profile: The Framingham Study. Am J Cardiol 1976;38:4651.

11. Michigan Heart Association: RISKO. Southfield, Mich, Michigan Heart Association, 1967.

12. Thomas PC, Cady LD, O'Connell ER, et al: Heart disease risk factors in Los Angeles County safety personnel. J Occup Med 1979;21:683-687.

13. US Department of Health and Human Services, Public Health Service, Health Care Financing Administration: The International Classification of Diseases, 9th revision, Clinical Modification. Washington, DC, 1980, vol 1, pp 358-403.

14. Jackson AS, Pollock ML: Generalized equations for predicting body density of men. Br J Nutr 1978;40:497-504.

15. Balke B, Ware R: An experimental study of physical fitness of Air Force personnel. US Armed Forces Med $J$ 1959;10:675688 .

16. American College of Sports Medicine: Guidelines for Graded Exercise Testing and Exercise Prescription, ed 2. Philadelphia, Lea \& Febiger, 1980, pp 23-28.
17. SAS Institute Inc: SAS User's Guide: Statistics. ed 5. Cary, NC, SAS Inc, 1985, pp 117-119.

18. Mantel N: Chi-square tests with one degree of freedom: Extensions of the Mantel-Haenszel procedure. J Am Stat Assoc 1963;58:690-700.

19. Shurtleff D: Some characteristics related to the incidence of cardiovascular disease and death: Framingham Study, 18year follow-up, Section 30, in Kannel WB, Gordon T (eds): The Framingham Study. Washington, DC, US Government Printing Office, 1974, pp 1-39.

20. Bruce RA, DeRouen TA, Hossack KF: Value of maximal exercise tests in risk assessment of primary coronary heart disease events in healthy men: Five years' experience of the Seattle Heart Watch Study. Am J Cardiol 1980;46:371-378.

21. Froelicher VF, Thomas MM, Pillow C, et al: Epidemiologic study of asymptomatic men screened by maximal treadmill testing for latent coronary artery disease. Am J Cardiol 1974;34:770776.

22. Evans AS: Subclinical epidemiology: The first Harry A. Feldman memorial lecture. Am J Epidemiol 1987;125:545-555.

The authors wish to express their sincere appreciation to the firefighters who participated in this study and to their technician staff for assistance in data collection. 


\section{Appendix}

The probability $(P)$ that CVD will occur within 8 years in a male firefighter initially free of CVD is given by the following equation:

$$
P=\frac{1}{1+\mathrm{e}^{-\mathrm{C}}}
$$

Where $\mathrm{C}$ is calculated using the following regression equation:

$\mathrm{C}=0.3743307$ (age) $-0.0021165(\text { age })^{2}+0.0258102$ (serum cholesterol concentration)

+0.0156953 (systolic blood pressure)

+0.5583013 (cigarette smoking*) +1.0529656 (left ventricular hypertrophy by ECG*)

+0.6020336 (glucose intolerance*)

-0.0003619 (serum cholesterol concentration $\times$ age) -19.7709560

* Denotes a dichotomous variable (yes, 1 ; no, 0 ).

For a more detailed description of the FSGCRP, see Kannel et al ${ }^{10}$ and Shurtleff. ${ }^{19}$ 